\title{
Decreased follicular steroids and insulin-like growth factor-I and increased atresia in diabetic gilts during follicular growth stimulated with PMSG
}

\author{
K. A. Meurer, N. M. Cox, I. A. Matamoros and R. C. Tubbs $\dagger$ \\ Department of Animal Science and $\nmid$ College of Veterinary Medicine, Mississippi State University \\ and Agricultural and Forestry Experiment Station, Mississippi State, MS 39762, USA
}

Summary. Four streptozotocin-diabetic gilts (maintained on exogenous insulin for 3 months) and 4 normoglycaemic gilts were treated with 600 i.u. PMSG. Diabetic gilts had insulin therapy removed at the time of PMSG administration. Plasma glucose averaged $463 \pm 5 \mathrm{mg} / 100 \mathrm{ml}$ for diabetic gilts and $82 \pm 4 \mathrm{mg} / 100 \mathrm{ml}$ for control gilts over the 72 -h sampling period. Serum insulin was lower in diabetic than in normoglycaemic gilts (glycaemic state by time interaction; $P<0.0001$ ). At ovary removal $75 \mathrm{~h}$ after PMSG, numbers and percentages of large $(\geq 7 \mathrm{~mm})$ and medium $(3-6 \mathrm{~mm})$ non-atretic follicles were similiar for diabetic and control gilts. The total percentage of non-atretic follicles $<3 \mathrm{~mm}$ was lower in diabetic than in control gilts (31 vs $68 \%$; s.e.m. $=7 ; P<0.05)$. Diabetic gilts had a greater percentage of atretic follicles over all size classes ( 50 vs $21 \%$; s.e.m. $=7 ; P<0.03$ ). After PMSG, LH was suppressed within $12 \mathrm{~h}$ in control gilts and remained similar to values in diabetic gilts until $72 \mathrm{~h}$, when LH was elevated in 2 diabetic gilts (glycaemic state by time interaction; $P<0.001$ ). Pulsatile LH patterns during 52-55 h after PMSG were not affected by glycaemic state. Serum concentrations of IGF-I tended $(P<0 \cdot 1)$ to be lower in diabetic gilts. Concentrations of oestradiol and FSH in serum were similar in diabetic and control gilts. Follicular fluid concentrations of oestradiol in follicles $\geq 7 \mathrm{~mm}$ were lower in diabetic than normoglycaemic gilts ( 341 vs $873 \mathrm{ng} / \mathrm{ml}$; s.e.m. $=86 ; P<0.05$ ). Testosterone was higher in follicles 3-6 mm in diameter in diabetic than in normoglycaemic gilts (142 vs $80 \mathrm{ng} / \mathrm{ml}$; s.e.m. $=26 ; P<0 \cdot 05$ ). Progesterone concentrations in follicular fluid were not affected by glycaemic state. Concentrations of IGF-I in follicles $\geq 7 \mathrm{~mm}$ were lower in diabetic than control gilts $(150$ vs $200 \mathrm{ng} / \mathrm{ml}$; s.e.m. $=13 ; P<0.05)$. We conclude that follicles of diabetic gilts respond to external gonadotrophic stimulation with decreased hormone production and increased ovarian follicular atresia, despite an absence of effects on circulating gonadotrophin and oestradiol concentrations.

Keywords: pig; diabetes; ovarian follicles; steroids; LH; IGF-I

\section{Introduction}

Insulin has been implicated in control of ovarian function in vivo and in vitro. In pigs, ovulation rate was increased by daily administration of insulin beginning 6 days before oestrus (Cox et al., 1987a). In studies to determine the effect of exogenous insulin on preovulatory follicular growth, we found that insulin administration reduced follicular atresia in cyclic (Matamoros et al., 1990) and PMSGtreated prepubertal gilts (Matamoros et al., 1991). Insulin administration also increased follicular fluid insulin-like growth factor-I (IGF-I) in PMSG-treated gilts (Matamoros et al., 1991). Insulin and IGF-I share certain differentiating and stimulatory actions on granulosa cells in vitro, including cell proliferation, progesterone secretion, aromatase activity and morphological development 
(May \& Schomberg, 1981; Baranao \& Hammond, 1984; Veldhuis et al., 1985; Adashi et al., 1985; Amsterdam et al., 1988; Caubo et al., 1989; Erickson et al., 1989).

Diabetes mellitus impairs reproductive function in rats (Kirchick et al., 1978) and humans (Djursing et al., 1982; Diamond et al., 1988). Administration of insulin replacement therapy to diabetics allows resumption of reproductive function (Davis et al., 1945; Kirchick et al., 1982). There is some evidence that diabetic pigs are fertile but observations were for 3 animals for which the severity of diabetes was not established (Ezekwe, 1986).

The present study was designed to explore further the role of insulin on reproductive function by examining the effects of diabetes mellitus during follicular growth. The objective was to characterize follicular development and concentrations of intrafollicular steroids and IGF-I as well as systemic LH, oestradiol and IGF-I in prepubertal diabetic gilts after stimulation with PMSG.

\section{Materials and Methods}

Induction of diabetes and sampling. Crossbred gilts from 3 litters were used, and littermates were assigned to either diabetic $(N=5)$ or control $(N=4)$ groups. Between 8 and 12 weeks of age (weight $17-31 \mathrm{~kg}$ ), pigs were tranquilized with xylazine (Haver Bayet Division, Miles Laboratories Inc., Shawnee, KS, USA; 0.5 mg/kg) and acepromazine maleate (Tech America Group, Inc., Elwood, KS, USA; $0.5 \mathrm{mg} / \mathrm{kg}$ ) and a polyethylene catheter was non-surgically and aseptically inserted into the anterior vena cava. Following the procedures of Gabel et al. (1985), $150 \mathrm{mg}$ streptozotocin $\mathrm{kg}$ (Lot\$0297d, Upjohn Co., Kalamazoo, MI, USA) was administered via the catheter, with the exception that the streptozotocin was at a concentration of $50 \mathrm{mg} / \mathrm{ml}$. The streptozotocin was administered within 2 min of its preparation.

A pig insulin suspension (Lente insulin, Squibb Novo, Inc., Princeton, NJ, USA) at an initial dose of $0.25 \mathrm{IU} / \mathrm{kg}$ was given once every $24 \mathrm{~h}$ to control hyperglycaemia. Blood glucose levels were monitored using Dextrostix (Miles Inc., Elkhart, IN, USA) and a portable meter. Adequate control was defined as blood glucose concentration between 30 and $80 \mathrm{mg} / 100 \mathrm{ml}$ approximately $3 \mathrm{~h}$ after injection, and doses of insulin were adjusted every 2 days to meet this criterion. The pigs had free access to water and were fed a standard growing swine ration (corn and soybean meal, $18 \%$ crude protein; NRC, 1987). Pigs were weighed weekly and control pigs had feed limited so that growth rates were equivalent to that of the diabetic gilts, which were fed ad libitum.

Although all streptozotocin-treated gilts initially became diabetic, defined as fasting plasma glucose $>200 \mathrm{mg} /$ $100 \mathrm{ml}$, one diabetic pig partly regained the ability to regulate glucose. This conclusion was based on a near-normal response to a glucose tolerance test and the fact that, upon necropsy at 1 year of age, the pancreas was enlarged; therefore, this pig was excluded from analyses. Another diabetic pig's cannula became nonfunctional; therefore, serum analyses are based on 4 normoglycaemic and 3 diabetic gilts. Follicle analyses represent 4 normoglycaemic and 4 diabetic gilts.

When the pigs were $151 \pm 4$ days of age and weighed $84 \pm 2 \mathrm{~kg}$, catheters were inserted as described above but without anaesthesia. On the next day, insulin therapy was removed, and 600 i.u. PMSG (Diasynth, Chicago, IL, USA) were injected intramuscularly at $06: 00 \mathrm{~h}$. Beginning immediately before PMSG injection, blood samples were taken at 6 -h intervals for $72 \mathrm{~h}$. Blood samples were also obtained for $3 \mathrm{~h}$ at 15 -min intervals to assess pulsatile secretion of LH beginning $52 \mathrm{~h}$ after injection of PMSG. At $75 \mathrm{~h}$ after PMSG pigs were unilaterally ovariectomized. The remaining ovary was left undisturbed to assess attainment of puberty in all gilts. Ketamine hydrochloride (Veterinary Products, Bristol Laboratories, Syracuse, NY, USA; $2 \mathrm{mg} / \mathrm{kg})$ and xylazine $(0.5 \mathrm{mg} / \mathrm{kg})$ were used as preanaesthetics and methoxyflurane (Pitman-Moore, Inc., Washington Crossing, NJ, USA) and nitrous oxide were used for general anaesthesia. Regular pig insulin (Iletin II, Eli Lilly and Co., Indianapolis, IN, USA; $0.05 \mathrm{IU} / \mathrm{kg}$ ) was given intramuscularly to the diabetic gilts immediately after the ovary was removed to aid recovery from surgery.

Follicles at the surface of the ovary were measured to the nearest $\mathrm{mm}$, follicular fluid was obtained, and follicles were assessed visually for macroscopic signs of atresia (opaqueness of follicle wall and viscosity of fluid immediately after removal) following the procedures of Moor et al. (1978) and Matamoros et al. (1990). Follicular fluid from individual follicles was diluted in $0.01 \mathrm{M}$-phosphate-buffered saline, containing $0.1 \%$ gelatin (PBS), $\mathrm{pH} 7.5$, to dilutions ranging from 1:10 to 1:40 depending on the amount of follicular fluid available, and fluid was frozen until assayed.

Assays. Serum LH concentrations were determined by a double-antibody RIA using a rabbit anti-porcine LH serum $(\$ 566)$ validated previously (Niswender et al. 1970; Cox et al., 1987a). Intra- and interassay coefficients of variation were 14 and $11 \%$, respectively, and sensitivity of the assay was $0.3 \mathrm{ng} / \mathrm{ml}$. Serum FSH concentrations were measured by an RIA validated in our laboratory (Cox et al., 1987a). Intra- and interassay coefficients of variation were 6.4 and $11.2 \%$ respectively, and sensitivity of the assay was $0.25 \mathrm{ng} / \mathrm{ml}$.

Stored follicular fluid was further diluted to concentrations of 1:100 or 1:200 in PBS for progesterone and testosterone RIA and to 1:1000 for medium-sized follicles, and 1:6000 for large-sized follicles for oestradiol RIA. Sample 
volumes of $200 \mu \mathrm{l}$ of the diluted fluid were assayed. Small $(<3 \mathrm{~mm})$ follicles were excluded from all hormone analyses due to insufficient follicular fluid volume. Progesterone concentrations were determined by a RIA validated in our laboratory (Rainey et al., 1990) with the exception that ${ }^{125}$ I-labelled progesterone (Ventrex Laboratory Inc., Portland, ME, USA; No 143, sp. act. $200 \mu \mathrm{Ci} / \mu \mathrm{g}$ ) was the isotope used. The standard was P 0130 progesterone (Sigma Chemical Co., St. Louis, MO, USA). Recovery values for progesterone corrected for endogenous source averaged $100.6 \% \pm 9$ when $0.156,0.312$, and $0.625 \mathrm{ng}$ exogenous progesterone were added to a serum pool. Intra- and interassay coefficients of variation were 13 and $18 \%$ respectively, and the sensitivity was $0.08 \mathrm{ng} / \mathrm{ml}$. A single extraction resulted in an $80 \%$ recovery of 20,000 c.p.m. $\left[1,2,6,7 \cdot{ }^{3} \mathrm{H}(\mathrm{N})\right]$ progesterone (NET-381, NEN Research Products, Boston, MA, USA), and values were corrected for recovery.

Concentrations of oestradiol were assayed by procedures previously validated in our laboratory for serum (Cox et al., 1987b) and follicular fluid (Matamoros et al., 1990). Intra- and interassay coefficients of variation were 14 and $20 \%$, respectively, and the sensitivity of the assay was $1.8 \mathrm{pg} / \mathrm{ml}$ in serum and $2.4 \mathrm{pg} / \mathrm{ml}$ in follicular fluid with recoveries of $95 \%$.

Serum and follicular fluid IGF-I concentrations were assayed according to the procedure of Houseknecht $e t$ al. (1988). In order to disassociate IGF-I from its binding proteins, $50 \mu \mathrm{l}$ serum or $50-200 \mu \mathrm{l}$ follicular fluid (diluted from $1: 10$ to $1: 40$ ) were incubated for 36 and $24 \mathrm{~h}$, respectively. The incubation solution ( $\mathrm{pH} 3 \cdot 2-3 \cdot 5$ ) contained $0.5-1 \cdot 0 \mathrm{ml}$ IGF-I assay buffer and $480 \mu \mathrm{l} 0.2 \mathrm{M}$-glycyl glycine $\mathrm{HCl}$. The first antibody was anti-somatomedin-C/IGF-I rabbit antiserum (UBK487, National Institute of Diabetes and Digestive and Kidney Diseases, National Institutes of Health, Baltimore, MD, USA) diluted at 1:2400 in 100 $\mu$ l IGF-I assay buffer containing normal rabbit serum at 1:200. The second antibody (sheep-anti-rabbit gamma globulin; MSU $\$ 24,9-13-83$ ) was diluted 1:10 in $50 \mu \mathrm{l}$ assay buffer. IGF-I standard was lot $\$ 1401-3$ (Amgen 141000, Amgen Biological, Thousand Oaks, CA, USA). The radiolabelled IGF-I was (3-( ${ }^{125}$ I) iodotyrosyl) insulin-like growth factor $\left(\mathrm{Thr}^{59}\right.$ ) (IGF, Amersham IM-172; Amersham Corp., Arlington Heights, IL, USA) and had a specific activity of $2000 \mathrm{Ci} / \mathrm{mmol}$. The average recovery of 50,100 and $200 \mathrm{pg}$ IGF-I added to $50 \mu \mathrm{l}$ serum and follicular fluid and corrected for endogenous IGF-I was $106 \%$, and increasing amounts of serum and follicular fluid $(25,50$ and $75 \mu 1)$ produced a curve parallel to the standard curve. The intra- and interassay coefficients of variation were 13 and $15 \%$, respectively, and the sensitivity was $6.0 \mathrm{ng} / \mathrm{ml}$ for serum and follicular fluid.

Concentrations of testosterone in follicular fluid were measured according to a procedure validated in our laboratory (Matamoros et al., 1990). Intra- and interassay coefficients of variation were 13 and $21 \%$ respectively, and the sensitivity of the assay was $0.08 \mathrm{ng} / \mathrm{ml}$ with extraction efficiency of $80 \%$. Concentrations of insulin in serum were measured by a procedure previously validated in our laboratory (Cox et al., 1987a). Intra- and interassay coefficients of variation were 8 and $15 \%$ respectively, and sensitivity of the assay was $0.04 \mathrm{ng} / \mathrm{ml}$. Glucose concentrations were measured in plasma by the glucose oxidase-peroxidase method as described by Cox et al. (1987a).

Statistical analyses. Proportions of non-atretic follicles in individual size classes were expressed as the percentages of total follicles present in each ovary. Proportions and numbers of follicles were analysed using one-way analysis of variance (Steel \& Torrie, 1980) with glycaemic state as the independent variable. For follicular fluid steroid concentrations and ratios, models included effects of glycaemic state, pig within glycaemic state (error term used to test effect of glycaemic state), follicle size class $(3-6 \mathrm{~mm}$ and $\geq 7 \mathrm{~mm})$, and the interaction. For plasma and serum concentrations of hormones and glucose, models included effects of glycaemic state, pig within glycaemic state (error term), time and the interaction. When main effects and interactions were significant, means were separated by the method of least significant difference (SAS, 1988).

The methods of Goodman \& Karsch (1980) were used to identify LH pulses. The criteria for LH pulses were: (1) a peak had to occur within 2 samples of the previous nadir; (2) the amplitude had to be greater than the sensitivity of the assay; and (3) the LH concentration at the peak had to exceed the $95 \%$ confidence limits of the concentrations at both the preceding and subsequent nadir. The baseline LH concentration was defined as the mean LH after peaks and values associated with the ascending phase of peaks were deleted, and the peak height was defined as the peak value minus the average baseline concentration for that animal. Variables obtained using these criteria were analysed for effects due to glycaemic state using one-way analysis of variance (SAS, 1988). Pearson correlation coefficients were calculated between all hormones measured in follicular fluid (SAS, 1988).

\section{Results}

Diabetic and normoglycaemic pigs responded similarly to PMSG with respect to numbers of follicles (Table 1). However, the percentage of non-atretic follicles $<3 \mathrm{~mm}$ and the percentage of macroscopically atretic follicles were significantly decreased and increased, respectively, in diabetic gilts. The influence of glycaemic state on the incidence of atresia was greatest in follicles $<3 \mathrm{~mm}$. The percentages of follicles $<3 \mathrm{~mm}$ which were atretic were 61 and $23 \%$ for diabetic and control animals, respectively (s.e.m. $=8 ; P<0.01$; data not in table). For follicles $3-6 \mathrm{~mm}$, incidence of atresia was similar for diabetic and control gilts $(12.7$ and $12.3 \%$, s.e.m. $=6)$. There were no macroscopically identifiable atretic follicles $\geq 7 \mathrm{~mm}$ in diameter. 
Table 1. Numbers and percentages of follicles

\begin{tabular}{lccccccc}
\hline & \multicolumn{3}{c}{ No. of follicles* } & & \multicolumn{3}{c}{$\%$ of total follicles* } \\
\cline { 2 - 3 } $\begin{array}{l}\text { Follicle } \\
\text { class }\end{array}$ & Control & Diabetic & s.e.m. & & Control & Diabetic & s.e.m. \\
\hline$<3 \mathrm{~mm}$ & 78 & 24 & 18 & & $68^{\mathrm{a}}$ & $31^{\mathrm{b}}$ & 7 \\
$3-6 \mathrm{~mm}$ & 6 & 6 & 4 & & 6 & 12 & 4 \\
$\geq 7 \mathrm{~mm}$ & 6 & 4 & 1 & & 6 & 7 & 2 \\
Atretic & 20 & 43 & 13 & & $20^{\mathrm{a}}$ & $50^{\mathrm{b}}$ & 7 \\
Total & 109 & 78 & 22 & & & & \\
\hline
\end{tabular}

*Values are least squares means and s.e.m.

${ }^{a, b}$ Within a row for percentages, means with different superscripts are different $(P<0.05)$.

Intrafollicular concentrations of IGF-I and oestradiol in follicles $\geq 7 \mathrm{~mm}$ in diameter were lower in diabetic than control gilts (Table 2). Diabetic gilts had higher concentrations of testosterone in follicles 3-6 mm (Table 2). There was no influence of glycaemic state on progesterone concentrations in follicular fluid. For all follicular fluid hormones, follicles $\geq 7 \mathrm{~mm}$ had higher concentrations than those $3-6 \mathrm{~mm}$ in diameter $(P<0.05$; not indicated in table $)$.

Table 2. Follicular fluid concentrations of IGF-I and steroids $(\mathrm{ng} / \mathrm{ml})$

\begin{tabular}{llcccc}
\hline $\begin{array}{l}\text { Follicle } \\
\text { class }\end{array}$ & State & IGF-1 & Oestradiol & Progesterone & Testosterone \\
\hline $3-6 \mathrm{~mm}$ & Control & $118 \pm 13$ & $67 \pm 81$ & $142 \pm 97$ & $80 \pm 16^{\mathrm{a}}$ \\
& Diabetic & $129 \pm 22$ & $55 \pm 128$ & $368 \pm 154$ & $142 \pm 26^{\mathrm{b}}$ \\
$\geq 7 \mathrm{~mm}$ & Control & $200 \pm 11^{\mathrm{a}}$ & $873 \pm 73^{\mathrm{a}}$ & $511 \pm 87$ & $97 \pm 15$ \\
& Diabetic & $150 \pm 13^{\mathrm{b}}$ & $341 \pm 86^{\mathrm{b}}$ & $853 \pm 103$ & $75 \pm 17$ \\
\hline
\end{tabular}

Values are least squares means \pm s.e.m.

a,b Within a column and size class, means with different superscripts are different $(P<0 \cdot 05)$.

In analyses relating follicular fluid hormone concentrations to diameter (regardless of size class), oestradiol was more positively correlated with diameter in normal $(r=0.8, P<0.0001)$ than diabetic $(r=0.46, P<0.03)$ gilts. Similarly, progesterone was positively correlated with diameter for normoglycaemic $(r=0.56, P<0.0002)$ and diabetic $(r=0.42, P<0.05)$ gilts. In contrast, IGF-I was correlated with diameter in normoglycaemic gilts only $(r=0.56 ; P<0.0002$ $v s r=0.28, P<0 \cdot 19)$. There were no effects of follicular diameter on testosterone in either group of animals.

Correlations among hormones in follicular fluid were significant for normoglycaemic pigs for the following pairs: oestradiol and testosterone $(r=0.41 ; P<0.01)$, oestradiol and progesterone $(r=0.72 ; P<0.0001)$, and oestradiol and IGF-I $(r=0.35 ; P<0.03)$. In contrast, for diabetic gilts, the only significant correlation was between oestradiol and progesterone $(r=0.47 ; P<0.03)$. There were no effects of glycaemic state on ratios of oestradiol to progesterone or oestradiol to testosterone in follicles $3-6 \mathrm{~mm}$ (Table 3). In follicles $\geq 7 \mathrm{~mm}$, diabetic gilts had significantly lower ratios of oestradiol to both progesterone and testosterone than did normoglycaemic gilts. The ratios of oestradiol to both progesterone and testosterone were affected by follicular diameter $(P<0.01)$, with follicles $\geq 7 \mathrm{~mm}$ having higher ratios than $3-6 \mathrm{~mm}$ follicles $(P<0.05$; not indicated in table).

Plasma glucose value was significantly higher and serum insulin lower in diabetic than control gilts throughout the entire 72-h sampling period (treatment by time interaction; $P<0.0001$ ). Also, diabetic gilts did not exhibit fluctuations in insulin similar to those in controls, for which insulin increased approximately every $24 \mathrm{~h}$, associated with morning feeding activity (Fig. 1). 
Table 3. Follicular fluid steroid ratios

\begin{tabular}{llcl}
\hline $\begin{array}{l}\text { Follicle } \\
\text { class }\end{array}$ & \multicolumn{1}{c}{ Steroids } & Control & Diabetic \\
\hline $3-6 \mathrm{~mm}$ & Oestradiol:progesterone & $0.40 \pm 0.3$ & $0 \cdot 04 \pm 0.4$ \\
& Oestradiol:testosterone & $0.04 \pm 1 \cdot 3$ & $0.44 \pm 2 \cdot 1$ \\
$\geq 7 \mathrm{~mm}$ & Oestradiol:progesterone & $2 \cdot 20 \pm 0 \cdot 2^{\mathrm{a}}$ & $0.40 \pm 0.3^{\mathrm{b}}$ \\
& Oestradiol:testosterone & $10 \cdot 30 \pm 1 \cdot 2^{\mathrm{b}}$ & $3.90 \pm 1 \cdot 4^{\mathrm{b}}$ \\
\hline
\end{tabular}

a.bWithin rows, means with different superscripts are different $(P<0.000 \mathrm{I})$.
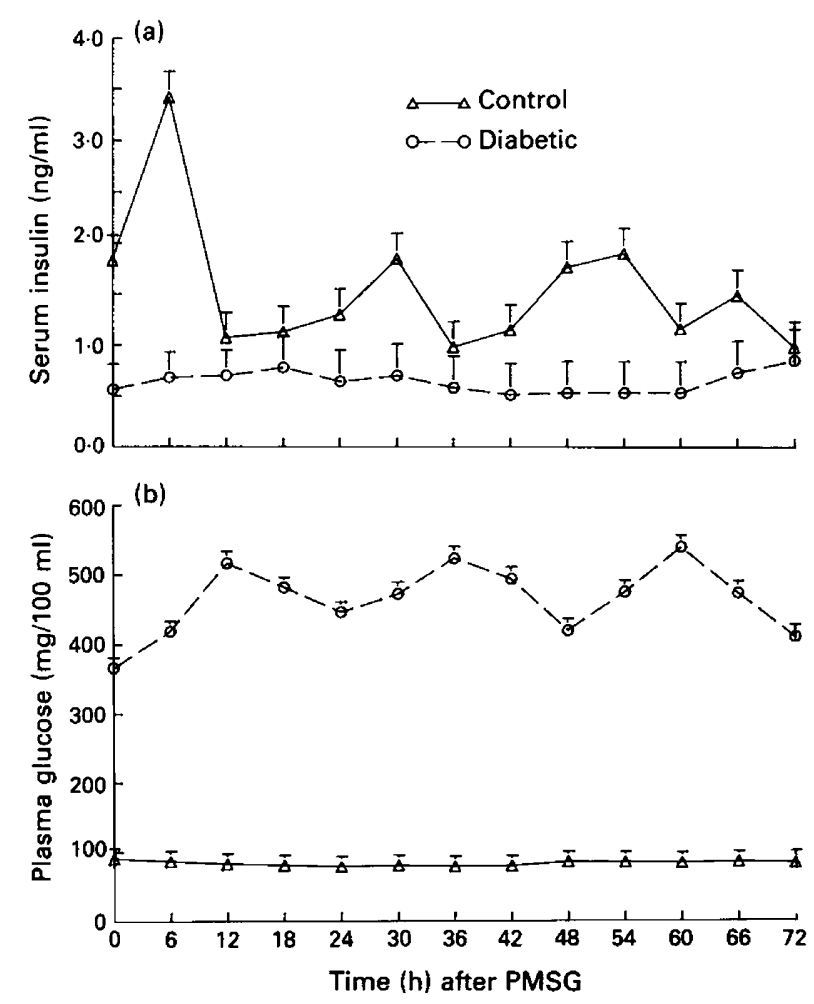

Fig. 1. Least squares means for concentrations of (a) insulin in serum and (b) glucose in plasma during $72 \mathrm{~h}$ after PMSG. Vertical lines represent the positive portion of the standard error of the mean.

Serum concentrations of IGF-I tended to be lower in diabetic gilts (effect of glycaemic state; $P<0 \cdot 1$ ). Concentrations of IGF-I averaged $68 \pm 3.9$ in diabetic and $104 \pm 2.6 \mathrm{ng} / \mathrm{ml}$ in normoglycaemic gilts over all sampling times.

Immediately before PMSG, serum LH was $0.04 \pm 0.02 \mathrm{ng} / \mathrm{ml}$ for diabetic gilts and $0.09 \pm 0.03$ $\mathrm{ng} / \mathrm{ml}$ for control gilts $(P<0.05$; Fig. 2). There was a treatment by time interaction for LH $(P<0.0001)$, and suppression of LH was evident within $12 \mathrm{~h}$ after PMSG. At $72 \mathrm{~h}$ after PMSG, LH in diabetic gilts was elevated $(P<0.01)$. This increase was due to the beginning of an apparent preovulatory LH surge in one diabetic gilt with values of 3 and $7 \mathrm{ng} / \mathrm{ml}$ at 66 and $72 \mathrm{~h}$ and another diabetic gilt with a value of $2 \mathrm{ng} / \mathrm{ml}$ at $72 \mathrm{~h}$ after PMSG. Concentrations of serum FSH were similar in diabetic and control gilts, respectively, averaging $0.60 \pm 0.04$ and $0.58 \pm 0.03 \mathrm{ng} / \mathrm{ml}$ over the sampling period. 
There was no influence of diabetes on serum oestradiol concentrations (Fig. 2). Oestradiol concentrations increased during the $72 \mathrm{~h}$ after PMSG and ranged from 2.5 to $20 \mathrm{pg} / \mathrm{ml}$ in normoglycaemic gilts (average $15 \pm 1 \cdot 3 \mathrm{pg} / \mathrm{ml}$ ) and from 3 to $23 \mathrm{pg} / \mathrm{ml}$ in diabetic gilts (average $19 \pm 1.9 \mathrm{pg} / \mathrm{ml})$.
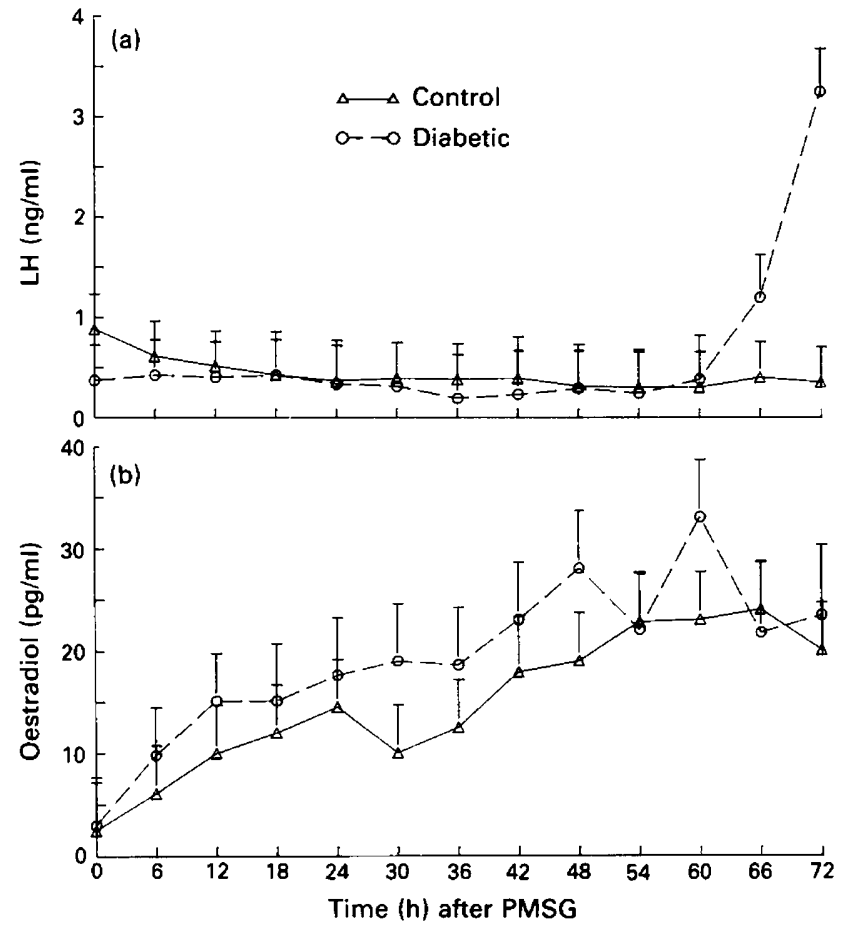

Fig. 2. Least squares means of concentrations of (a) $\mathrm{LH}$ and (b) oestradiol in serum during $72 \mathrm{~h}$ after PMSG. Vertical lines represent the positive portion of the standard error of the mean.

From 52-55 h after PMSG, there were no effects of glycaemic state on number of LH peaks $(1.30$ vs 1.25 , s.e.m. $=0.45)$, amplitude $(0.17$ vs $0.22 \mathrm{ng} / \mathrm{ml}$, s.e.m. $=0.07)$, baseline $(0.24$ vs 0.33 $\mathrm{ng} / \mathrm{ml}$, s.e.m. $=0.04)$ or overall average $\mathrm{LH}(0.32$ vs $0.41 \mathrm{ng} / \mathrm{ml}$, s.e.m. $=0.06)$ in diabetic and control gilts, respectively.

\section{Discussion}

One of the major effects of diabetes in this study was an increase in atresia of small follicles in diabetic compared with normal gilts despite similar numbers of larger follicles which were not visibly atretic. In earlier studies we reported that insulin administration to normoglycaemic cyclic gilts caused a dramatic reduction in atresia of preovulatory-sized follicles (Matamoros et al., 1990). However, in normoglycaemic PMSG-treated prepubertal gilts, the converse of the present study was observed; insulin reduced atresia in small $(<3 \mathrm{~mm})$ follicles only (Matamoros et al., 1991). Together these observations suggest a role for insulin in prevention of follicular atresia.

Since ovaries were not examined during the period of insulin therapy before this experiment, conclusions cannot be made about possible differences in atresia which may have existed before PMSG administration. However, when insulin therapy was resumed for these diabetic gilts after this experiment, function of the remaining ovary appeared normal, since there was no influence 
of glycaemic state on age at puberty ( $183 \pm 3$ days for normoglycaemic and $187 \pm 4$ days for diabetic gilts) and subsequent cyclicity (Meurer et al., 1990). There is therefore no evidence that hypothalamo-pituitary maturation or ovarian function was delayed by diabetes.

The diabetic gilts initially responded to PMSG in the same way as did the control gilts, as shown by equivalent numbers of follicles $\geq 3 \mathrm{~mm}$. Similar ovulatory responses to exogenous gonadotrophins were evident in normal and diabetic mice (Diamond et al., 1989); similar numbers of oocytes were recovered from normal and diabetic mice, but maturation of oocytes from diabetic mice was delayed. In contrast, diabetic rats did not ovulate in response to PMSG (Kirchick et al., 1982). The present study did not address whether diabetic pigs would ovulate after PMSG but, based on the number of follicles of preovulatory size, PMSG recruitment of follicles probably began normally in the diabetic gilts.

Despite the absence of macroscopic morphological differences in follicles $\geq 3 \mathrm{~mm}$ in diameter, diabetes was associated with lowered concentrations of several intrafollicular hormones. Oestradiol concentration was decreased by diabetes in large non-macroscopically atretic follicles $(\geq 7 \mathrm{~mm}$ ), which are of the size most likely to be preovulatory (Foxcroft \& Hunter, 1985). Ainsworth et al. (1980) and Hammond et al. (1988) reported that oestradiol concentrations increased steadily in follicles of increasing size for up to $72 \mathrm{~h}$ after PMSG. Measurement of oestradiol in serum alone would not have reflected the decreased follicular oestradiol caused by diabetes in this study. Follicles of diabetics produced oestradiol sufficient to trigger an LH surge, but later oestradiol secretion appeared to lessen, as indicated by lowered oestradiol values in large follicles at $75 \mathrm{~h}$ after PMSG. It is likely that serum oestradiol would have triggered a preovulatory LH surge in the other diabetic gilts, but it is not known how follicles would respond to the ovulatory stimulus.

In diabetic gilts elevated testosterone concentrations in medium-sized follicles as well as lowered oestradiol in large-sized follicles may indicate decreased aromatization to oestradiol as follicles increase in size. The ratios of oestradiol to other steroids also support the concept that steroidogenic pathways are altered by the diabetic condition, since the ratios of oestradiol to progesterone and oestradiol to testosterone in follicles $\geq 7 \mathrm{~mm}$ in diameter were significantly reduced in diabetic animals. Reduced ratios of oestrogen to total follicular androgens precede macroscopically visible atresia in all sizes of follicles and the lack of oestrogen reflects a limitation in the aromatizing system (Moor et al., 1978; McNatty et al., 1979; Carson et al., 1981). These findings support the conclusion that preovulatory-sized follicles of diabetic gilts in the present study were in early stages of atresia, although there were no macroscopic indications of atresia detected.

The indication of a preovulatory LH surge in 2 diabetic gilts is in contrast to the results of Kirchick et al. (1982) for diabetic rats treated with PMSG. Exposure to the preovulatory LH surge could be expected to alter intrafollicular steroid concentrations. Decreased steroid concentrations in pig follicles were not evident by $4 \mathrm{~h}$ but were evident at $18 \mathrm{~h}$ after an ovulatory injection of hCG (Ainsworth et al., 1980). In our study, elevation of $\mathrm{LH}$ in 2 diabetic pigs was first evident in the samples obtained $3 \mathrm{~h}$ and $9 \mathrm{~h}$ before ovary removal, respectively. Therefore it is likely that one diabetic animal could have experienced significant exposure to LH. However, when data were examined individually, concentrations of follicular fluid steroids and IGF-I as well as ratios of oestradiol to testosterone and progesterone and serum oestradiol values of these diabetic gilts were not distinguishable from those of the other diabetic gilts. The results of this study are supported by a comparison of diabetic and normoglycaemic gilts on Day 18 of the oestrous cycle, in which none of the gilts had experienced an LH surge and yet follicular hormone differences were similar to those in the present study (Meurer et al., 1990).

Lack of insulin in diabetic gilts was associated with lowered IGF-I values in large follicles and an absence of correlation between IGF-I and follicular diameter. We know of no other reports of effects of diabetes on intrafollicular IGF-I in pigs. However, Matamoros et al. (1991) observed that exogenous insulin administration doubled IGF-I concentrations in follicles of PMSG-treated normoglycaemic gilts. In vivo IGF-I increased in follicular fluid in response to PMSG, suggesting 
that intrafollicular IGF-I content is regulated by gonadotrophins (Hammond et al., 1988). Also, intrafollicular IGF-I concentrations were correlated with size of pig follicles, in contrast to intrafollicular concentrations of insulin (Hammond et al., 1985). Our data indicate that the lack of insulin prevented the PMSG-induced increase in intrafollicular IGF-I as follicles developed.

In the present study concentrations of IGF-I and oestradiol were positively correlated in normoglycaemic but not in diabetic gilts. Eden et al. (1988) also reported a positive correlation between IGF-I and oestradiol concentration in normal follicles. In diabetic pigs the lack of correlation between oestradiol and IGF-I provides further evidence for a disruption in follicular hormone production. There were positive correlations in normoglycaemic animals between oestradiol and testosterone, progesterone and IGF-I. However, in diabetic gilts the only positive correlation was between oestradiol and progesterone. Assuming that the correlations in control gilts are respresentative of normal preovulatory follicles, this is further support for the argument that aromatization does not progress normally in the absence of insulin. Aromatase activity of granulosa cells in vitro was increased by both insulin (Garzo \& Dorrington, 1984) and IGF-I (Erickson et al., 1989). The impairment of steroidogenesis in this study may be primarily related to the lack of insulin and secondarily related to lowered intrafollicular IGF-I.

In contrast to results with follicular fluid, significant effects of diabetes were not observed for serum IGF-I concentrations. Inhibitory effects of diabetes on systemic IGF-I have been observed by others. Bornfeldt et al. (1989) reported that messenger RNA levels for IGF-I in body organs are lowered in diabetes. An additional mechanism by which diabetes decreases systemic IGF-I may be by causing higher concentrations of its binding protein (Holly \& Wass, 1989). Hammond et al. (1988) concluded that serum and follicular fluid IGF-I concentrations are not necessarily correlated in pigs. However, Eden et al. (1988) observed that IGF-I concentrations in follicles were correlated with those in the circulation except for the dominant follicle of humans, in which IGF-I was elevated.

Circulating gonadotrophins were not decreased by diabetes. Kirchick et al. (1978) observed that basal LH was similar in diabetic and control rats. In contrast to the present study, in rats diabetes abolished the oestradiol-induced LH surge, which was restored by insulin (Kirchick et al., 1978, 1982; Katayama et al., 1984). Also, results from our laboratory indicate that ovariectomized diabetic pigs have a preovulatory LH surge in response to oestradiol benzoate (Carlton et al., 1990). Serum FSH was similar in diabetic and control gilts in this study and there was no increase in FSH after PMSG administration, in agreement with the results of Flowers et al. (1989). Peripheral FSH concentration was not affected by insulin administration to normoglycaemic PMSG-treated gilts (Matamoros et al., 1991).

The failure of diabetes to affect circulating gonadotrophin values argues against a role for the hypothalamo-pituitary complex in the impairment of steroidogenesis observed in this study. In our earlier studies, we observed that effects of insulin on ovulation rate were not necessarily associated with changes in gonadotrophins (Cox et al., 1987a; Matamoros et al., 1991). Although not tested directly in the present study, lack of insulin may have interfered with the action of gonadotrophins on granulosa cells. A synergism of both insulin and IGF-I with gonadotrophins to enhance granulosa cell function is well-established (Adashi et al., 1985; Poretsky \& Kalin, 1987).

In summary, the numbers of presumed preovulatory follicles at $75 \mathrm{~h}$ after PMSG were not affected by diabetes, although atresia of small follicles was increased. However, although numbers and gross morphology of follicles $\geq 3 \mathrm{~mm}$ in diameter were similar, the ability of follicles to produce oestradiol, testosterone and IGF-I was impaired in diabetic gilts. This impairment was in spite of apparently adequate concentrations of $\mathrm{LH}$ in serum and progesterone and testosterone in large follicles. We therefore conclude that the diabetic condition, the subsequent lack of insulin, and possibly the lack of IGF-I, impair steroidogenesis at some point subsequent to progesterone production. 
This research was supported by the Mississippi Pork Producers' Association and Mississippi Agricultural and Forestry Experiment Station (Publication number J-7435).

We thank A. B. Moore for technical assistance; Dr J. W. Lauderdale, The Upjohn Company, for streptozocin; Dr G. D. Niswender, Colorado State University, for LH antiserum; Dr L. E. Reichert, Albany Medical College, for purified LH; and the National Hormone and Pituitary Program for IGF-I antiserum.

\section{References}

Adashi, E.Y., Resnick, C.E., D'Ercole, A.J., Svoboda, M.E. \& Van Wyk, J.J. (1985) Insulin-like growth factors as intraovarian regulators of granulosa cell growth and function. Endocr. Rev. 6, 400-420.

Ainsworth, L., Tsang, B.K., Downey, B.R., Marcus, G.J. \& Armstrong, D.T. (1980) Interrelationships between follicular fluid steroid levels, gonadotropic stimuli, and oocyte maturation during preovulatory development of porcine follicles. Biol. Reprod. 23, 621-627.

Amsterdam, A., May, J.V. \& Schomberg, D.W. (1988) Synergistic effect of insulin and follicle-stimulating hormone on biochemical and morphological differentiation of porcine granulosa cells in vitro. Biol. Reprod. 29, 379-390.

Baranao, J.L.S. \& Hammond, J.M. (1984) Comparative effects of insulin and insulin-like growth factors on DNA synthesis and differentiation of porcine granulosa cells. Biochem. Biophys. Res. Commun. 124, 484-490.

Bornfeldt, K.E., Arnqvist, H.J., Enberg, B., Mathews, L.S. \& Norstedt, G. (1989) Regulation of insulin-like growth factor-I and growth hormone receptor gene expression by diabetes and nutritional state in rat tissues. J. Endocr. 122, 651-656.

Carlton, C.A., Cox, N.M. \& Barb, C.R. (1990) Luteinizing hormone response to estradiol benzoate in diabetic ovariectomized gilts. Biol. Reprod. 42 (Suppl. 1), 152, abstr.

Carson, R.S., Findlay, J.K., Clarke, I.J. \& Burger, H.G. (1981) Estradiol, testosterone, and androstenedione in ovine follicular fluid during growth and atresia of ovarian follicles. Biol. Reprod. 24, 105-113.

Caubo, B., DeVinna, R.S. \& Tonetta, S.A. (1989) Regulation of steroidogenesis in cultured porcine theca cells by growth factors. Endocrinology 125, 321-326.

Cox, N.M., Stuart, M.J., Althen, T.G., Bennett, W.A. \& Miller, H.W. (1987a) Enhancement of ovulation rate in gilts by increasing dietary energy and administering insulin during follicular growth. J. Anim. Sci. 64, $507-516$.

Cox, N.M., Ramirez, J.L., Matamoros, I.A., Bennett, W.A. \& Miller, H.W. (1987b) Influence of season on estrous and luteinizing hormone responses to estradiol benzoate in ovariectomized sows. Theriogenology 27, 395-405.

Davis, M.E., Fugo, N.W. \& Lawrence, K.G. (1945) Effect of alloxan diabetes on reproduction in the rat. Expl Biol. Med. 59, 638-641.

Diamond, M.P., Wentz, A.C. \& Cherrington, A.D. (1988) Alterations in carbohydrate metabolism as they apply to reproductive endocrinology. Fert. Steril. 50, 387-397.

Diamond, M.P., Moley, K.H., Pellicer, A., Vaughn, W.K. \& DeCherney, A.H. (1989) Effects of streptozotocin- and alloxan-induced diabetes mellitus on mouse follicular and early embryo development. J. Reprod. Fert. 86, 1-10.

Djursing, H., Nyholm, H.C., Hagen, C., Carensen, G. \& Pederson, L.M. (1982) Clinical and hormonal characteristics in women with anovulation and insulintreated diabetes mellitus. Am. J. Obstet. Gynecol. 143, 876-882.

Eden, J.A., Jones, J., Carter, G.D. \& Alaghbanc-Zadeh, J. (1988) A comparison of follicular fluid levels of insulin-like growth factor-I in normal dominant and cohort follicles, polycystic, and multicystic ovaries. Clin. Endocr. 29, 327-336.

Erickson, G.F., Garzo, V.G. \& Magoffin, D.A. (1989) Insulin-like growth factor-I regulates aromatase activity in human granulosa and granulosa luteal cells. J. clin. Endocr. Metab. 69, 716-723.

Ezekwe, M.O. (1986) Effect of streptozotocin-induced diabetes in primiparous swine on subsequent reproductive performance. J. Anim. Sci. 62, 1005-1011.

Flowers, B., Martin, M.J., Cantley, T.C. \& Day, B.N. (1989) The effect of pregnant mare's serum gonadotropin on follicle stimulating hormone and estradiol secretion in the prepubertal gilt. Anim. Reprod. Sci. 21, 93-100.

Foxcroft, G.R. \& Hunter, M.G. (1985) Basic physiology of follicular maturation in the pig. J. Reprod. Fert., Suppl. 33, 1-9.

Gabel, H., Bitter-Suermann, H., Henriksson, C., SaveSoderbergh, J., Lundhom, K. \& Brynger, H. (1985) Streptozotocin diabetes in juvenile pigs. Evaluation of an experimental model. Horm. Metab. Res. 17, $275-280$

Garzo, V.G. \& Dorrington, J.H. (1984) Aromatase activity in human granulosa cells during follicular development and the modulation of follicle-stimulating hormone and insulin. Am. J. Obstet. Gynecol. 148, $657-662$.

Goodman, R.L. \& Karsch, F.J. (1980) Pulsatile secretion of luteinizing hormone: differential suppression by ovarian steroids. Endocrinology 107, 1286-1290.

Hammond, J.M., Baranao, J.L.S., Shaleris, D., Knight, A.B., Ramanus, J.A. \& Rechler, M.M. (1985) Production of insulin-like growth factors by ovarian granulosa cells. Endocrinology 17, 2553-2555.

Hammond, J.M., Hsu, C., Klindt, J., Tsang, B.K. \& Downey, B.R. (1988) Gonadotropins increase concentrations of immunoreactive insulin-like growth factor-I in porcine follicular fluid in vivo. Biol. Reprod. 38, 304-308.

Holly, J.M.P. \& Wass, J.A.H. (1989) Insulin-like growth factors; autocrine, paracrine or endocrine? New perspectives of the somatomedin hypothesis in the light of recent developments. J. Endocr. 122, 611-618. 
Houseknecht, K.L., Boggs, D.L., Campion, D.R., Sartin, J.L., Kiser, T.E., Rampacek, G.B. \& Amos, H.E. (1988) Effect of dietary energy source and level on serum growth hormone, insulin-like growth factor-I, growth and body composition in beef heifers. $J$. Anim. Sci. 66, 2907-2915.

Katayama, S., Brownsheidle, C.M., Wootten, V., Lee, J.B. \& Shimaoka, K. (1984) Absent or delayed preovulatory luteinizing hormone surge in experimental diabetes mellitus. Diabetes 33, 324-327.

Kirchick, H.J., Keyes, P.L. \& Frye, B.E. (1978) Etiology of anovulation in the immature alloxan-diabetic rat treated with pregnant mare's serum gonadotropin: absence of the preovulatory luteinizing hormone surge. Endocrinology 102, 1867-1873.

Kirchick, H.J., Keyes, P.L. \& Frye, B.E. (1982) Restoration of the LH surge and ovulation by insulin in alloxan-diabetic immature rats treated with pregnant mare's serum gonadotropin. Acta endocr., Copenh. 100, 266-273.

Matamoros, I.A., Cox, N.M. \& Moore, A.B. (1990) Exogenous insulin and additional dietary energy affect preovulatory follicular steroid concentrations and granulosa cell $\mathrm{LH} / \mathrm{hCG}$ binding in swine. Biol. Reprod. 43, 1-9.

Matamoros, I.A., Cox, N.M. \& Moore, A.B. (1991) Effects of exogenous insulin and body condition on metabolic hormones and gonadotropin-induced follicular development in prepubertal gilt. J. Anim. Sci. 69, (in press).

May, J.V. \& Schomberg, D.W. (1981) Granulosa cell differentiation in vitro: Effect of insulin on growth and functional integrity. Biol. Reprod. 25, $421-431$.

MeNatty, K.P., Smith, D.M., Makris, A., Osathanondh, R. \& Ryan, K. (1979) The microenvironment of the human antral follicle: Interrelationships among the steroid levels in antral fluid, the population of granulosa cells, and the status of the oocyte in vivo and in vitro. J. clin. Endocr. Metab. 49, 851-860.

Meurer, K.A., Cox, N.M. \& Tubbs, R.C. (1990) Absence of insulin affects recruitment and maintenance of preovulatory follicles in cyclic diabetic gilts. J. Anim. Sci. 68 (Suppl. 1), 466, abstr.

Moor, R.M., Hay, M.F., Dott, H.M. \& Cran, D.G. (1978) Macroscopic identification and steroidogenic function of atretic follicles in sheep. $J$ Endocr. 77, 309-318.

Niswender, G.D., Reichert, L.E. \& Zimmerman, D.R. (1970) Radioimmunoassay of serum levels of luteinizing hormone throughout the estrous cycle of pigs. Endocrinology 87, 576-580.

NRC (1987) Nutrient Requirements of Swine, 9th Revised edn. National Academy Press, Washington, D.C.

Poretsky, L. \& Kalin, M.A. (1987) The gonadotropic function of insulin. Endocrine Rev. 8, 132-141.

Rainey, M.R., Tubbs, R.C., Cox, N.M. \& Bennett, L.W. (1990) Prepubertal exposure to dietary zearalenone alters hypothalamo-hypophysial function but does not impair post-pubertal reproductive function of gilts. J. Anim. Sci. 68, 2015-2022.

SAS (I988) SAS/STAT User's Guide. SAS Institute Inc., Cary, NC.

Steel, R.G.D. \& Torrie, J.H. (1980) Principles and Procedures of Statistics. McGraw-Hill Book Co., New York.

Veldhuis, J.D., Kolp, L.A., Juchter, D., Veldhuis, P. \& Garmey, J. (1985) Mechanisms subserving insulin's differentiating actions on progestin biosynthesis by ovarian cells: Studies with cultured swine granulosa cells. Endocrinology 116, 651-659.

Received 10 April 1990 